\title{
Margins and monsters:
}

\section{How some micro cases lead to macro claims}

\author{
Chuanfei Chin \\ University of Oxford and National University of Singapore \\ phiccf@nus.edu.sg
}

How do micro cases lead us to surprising macro claims? Historians often say that the micro level casts light on the macro level. This metaphor of 'casting light' suggests that the micro does not illuminate the macro straightforwardly; such light needs to be interpreted. In this essay, I propose and clarify six interpretive norms to guide micro-to-macro inferences.

I focus on marginal groups and monsters. These are popular cases in social and cultural histories, and yet seem to be unpromising candidates for generalization. Marginal groups are dismissed by the majority as inferior or ill-fitting; their lives seem intelligible but negligible. Monsters, on the other hand, are somehow incomprehensible to society and treated as such. First, I show that, by looking at how a society identifies a marginal group and interacts with it, we can draw surprising inferences about that society's self-image and situation. By making sense of a monster's life, we can draw inferences about its society's mentality and intelligibility. These will contest our conception of a macro claim. Second, I identify four risks in making such inferences-and clarify how norms of coherence, challenge, restraint, connection, provocation, and contextualization can manage those risks. My strategy is to analyze two case studies, by Richard Cobb, about a band of violent bandits and a semi-literate provincial terrorist in revolutionary France. Published in 1972, these neglected studies show Cobb to be an inventive and idiosyncratic historian, who created new angles for studying the micro level and complicated them with his autobiography. They illustrate how a historian's autobiographical, literary and historiographical interests can mix into a risky, and often rewarding, style.

marginal; monster; microhistory; norms of interpretation; context; autobiography; historiography 


\section{Acknowledgements}

This essay was written while I was a doctoral scholar funded by the British Society for the Philosophy of Science. An earlier version was presented during a session on microhistory at the International Society for Cultural History 2010 Conference, held at the University of Turku, Finland. I am grateful for comments from the audience, especially those from Jacques Revel, Sven-Erik Klinkmann, and Sigurður Gylfi Magnússon. Gavin Maughfling read and commented on the first and last drafts. 


\section{Margins and monsters: \\ How some micro cases lead to macro claims}

\section{Introduction}

How do micro cases in history lead us to surprising macro claims? I shall look at two types of case studies that pose this challenge starkly. ${ }^{1}$ The first type deals with marginal groups, the second with monsters. Let me define these roughly. Marginal groups are exceptions in a society. They are dismissed by the majority as inferior or ill-fitting. Their lives seem intelligible to others but also negligible. Monsters, on the other hand, are incomprehensible in some way to their society and treated as such. Their behavior is extreme; others are tempted to call it evil or inhuman. Of course, a monster can appear from the margins, and a society may choose to ostracize its monsters as a group-I do not mean for these types to exclude each other. I ask about both types: How are their lives, visible mostly at the micro level, relevant to history at the more macro level?

These exceptions and extremes seem to be unpromising material for any generalization. Yet some historians are drawn to them. They reconstruct the network of rules and practices through which society discriminates against a marginal group. Or they record how a monster struggles against societysometimes erupting in early and violent rebellion, sometimes thriving in surprising ways before capture and control, then languishing in mute isolation. To infer from micro to macro: these relations between society and its margins or monsters can cast light on that society. I note how often this metaphor of 'casting light' recurs when historians discuss their case studies. It suggests that

\footnotetext{
${ }^{1}$ Two surveys of historical methods discuss this challenge more generally: Giovanni Levi, 'On Microhistory,' and Jim Sharpe, 'History from Below,' both in New Perspectives on Historical Writing, ed. Peter Burke, 2nd ed. (Cambridge, UK: Polity Press, 2001), 97-119, 25-42. I also recommend Microhistory and the Lost Peoples of Europe, ed. Edward Muir and Guido Ruggiero (Baltimore: Johns Hopkins University Press, 1991) and Carlo Ginzburg, Clues, Myths, and the Historical Method, transl. John Tedeschi and Anne C. Tedeschi (Baltimore: Johns Hopkins University Press, 1992).
} 
the micro does not illuminate the macro straightforwardly. Such light, when cast on a backdrop of already vague social and cultural contours, needs to be interpreted.

In this essay, I propose six interpretive norms to guide these micro-to-macro inferences. My strategy is to analyze two case studies in Richard Cobb's Reactions to the French Revolution, which are admired by other historians, even those with different methodological and ideological leanings. ${ }^{2}$ His studies try to make sense of the strange lives led by a band of violent bandits and a semiliterate provincial terrorist. They offer different surprises about the revolutionary era: French society was even less like the margins than it had asserted, and more like the monsters than it had assumed. First, I shall argue that these surprises involve new micro-to-macro inferences about French society's self-image, situation, mentality, and intelligibility. Some of them challenge our conception of a macro claim. Then I will identify four risks in Cobb's inferences and the rigors that he applies to manage those risks.

A worry arises immediately. Might the crafting of case studies be akin to an art? If so, is this art amenable to analysis? ${ }^{3}$ Let me stress that my aim is not to codify microhistory's practices, but to clarify a historian's method-a method that, I claim, shares some of the aims and tactics of microhistory and casts light on their problems. When I came by Cobb's book two years ago, I was struck by his voice. Its compelling tone is hard to capture: highly personal, frank with prejudices, but rich with empathy for his subjects and authority over his sources. Cobb has been praised too for his novelist's imagination and eye for detail. This praise is not

\footnotetext{
2 Richard Cobb, Reactions to the French Revolution (Oxford: Oxford University Press, 1972), chaps. 3-5. I have learned from three essays by Cobb's former pupils: Martyn Lyons, 'Cobb and the Historians,' in Beyond the Terror: Essays in French Regional and Social History 1794-1815, ed. Gwynne Lewis and Colin Lucas (Cambridge, UK: Cambridge University Press, 1983), 1-20; Gwynne Lewis, 'Richard Cobb, 1917-1996,' History Workshop Journal 42 (1996), 244-247; and Colin Jones, 'Olwen Hufton's 'Poor', Richard Cobb's 'People', and the Notions of the longue durée in French Revolutionary Historiography,' Past and Present 1 (2006), 178-203.

${ }^{3}$ This worry also crops up when case studies are used in the social sciences. See John Gerring, Case Study Research: Principles and Practice (Cambridge, UK: Cambridge University Press, 2006), 5-8.
} 
wrongheaded, but it does not show how the autobiographical, literary, and historiographical interests of his case studies are linked. I want to clarify this link by making explicit those historiographical norms in Cobb's method that draw on autobiographical and literary interests.

To do so, I must simplify, with an outsider's eye, the texture of his case studies. I speak of the macro level in these case studies, even though they refer to a range of macro levels. I neglect their links with other historiographical and ideological debates about the French Revolution. Instead, I draw on what others say about microhistory's use of the 'significant clue,' the 'telling detail,' and the 'exceptional normal.' ${ }^{4}$ My aim is to translate what I have learned about these provocative abstractions into concrete applications. My blunt approach-listing every micro-to-macro inference and interpretive norm implied, however obvious to the historian-brings two benefits. First, it makes available to the new historian and the non-historian such inferences and norms. Second, it highlights to the historian some aspects of historiography that most resist codification.

\section{Margins}

On November 4, 1799, the public prosecutor in Chartres drew up an indictment of 118 persons. They were members and accomplices of the bande d'Orgères-a gang of bandits charged with ninety-five murderous operations between 1791 and 1799. The band lived on the margins of the Beauce and terrorized the countryside near Chartres, though it used Paris to recruit children and ventured at least twice to the Seine-et-Marne. It targeted farms, inns, and shops. The band was cohesive and organized, forming what Cobb calls 'a Counter-Society' and 'an

\footnotetext{
4 See, for instance, Ginzburg, 'Clues: Roots of an Evidential Paradigm'; Carlo Ginzburg, 'Microhistory: Two or Three Things That I Know about It,' Critical Inquiry 20 (1993), 10-35; Jacques Revel, 'Microanalysis and the Construction of the Social,' in Histories: French Constructions of the Past, ed. Jacques Revel and Lynn Hunt, transl. Arthur Goldhammer (New York: The New Press, 1996), 492-502; and Levi, 'On Microhistory,' 97-119.
} 
Anti-State. ${ }^{5}$ Most members had criminal pasts; many had family and lovers in the band. To collect information, some worked temporarily for farmers and bribed locals. Others took part in violent robberies and murders. Stolen goods were processed, often by the women, then dispersed by those disguised as peddlers and merchants. Cobb uses police and judicial archives in the provinces to reconstruct the bandits' lives in vivid detail. To pick just one example that sticks in my mind: he notes that Saturday was 'often the day most favored for their operations, thus ensuring an agreeable Sunday sharing out the spoils, in their new finery, in the auberge. ${ }^{6}$

I cannot do justice here to Cobb's detective work. My interest is more narrowly historiographical: How does his micro study of the band contribute to our macro understanding of French society? We need to test if his description of life on the margins tells us anything valuable about life among the majority. This test faces two prima facie difficulties. First, there are no obvious causal connections between the band and the Revolution. It 'cannot be said either to have influenced, or been influenced by, the course of the Revolution. ${ }^{, 7}$ At most, economic distress during the Revolution supplied the band with ready recruits. Second, the band lived under its own code and hierarchy. It seemed to relish its separate status as an anti-state.

\subsection{Identifications and Interactions}

I find two ways to make micro-to-macro inferences in this case. The first looks at how the marginal group was identified by outsiders, the second at how it interacted with them. Identifications can be revealing. The terms by which a marginal group was identified, then dismissed as exceptional, tell us about the majority's self-image. Studying the prosecutor's 1799 indictment, Cobb describes

\footnotetext{
${ }^{5}$ Cobb, Reactions to the French Revolution, 10.

${ }^{6}$ Ibid., 196. But see 206n.

${ }^{7}$ Ibid., 125.
} 
the band as 'a society that was able to live outside all the usual terms of reference of normal behavior-a body, in fact, that was complete in itself, with its own codes, providing for its own lusty pleasures and even organized for the future, with the provision for the education of its younger members. ${ }^{8}$ This prosecutor condemned the band for its 'habits of crime, idleness and profligacy.' He charged that children as young as 10 to 12 had been recruited and trained to be thieves and killers. We can infer that these habits were not, from the majority's point of view, normal behavior. ${ }^{9}$ They did not belong to its self-image: that body of assumptions about itself that guards its identity and guides its action, including its judgment of others.

Our initial conclusion offers no surprise. It is even a little disappointing. But we can draw a more subtle inference from Cobb's insistence that the band was 'complete in itself.' What justifies this insistence? This marginal group was similar in some ways to the majority: it had codes of behavior, as well as policies about pleasure and posterity. It prized women with good looks. The band formed 'a complete society, with family relationships and in which women had a major part to play. ${ }^{10}$ It even divided the territory of this anti-state into départements and cantons-a mocking semblance of the French state. ${ }^{11}$ Often its most striking differences from the majority obscure similarities of interest and purpose. We are so outraged by children being trained in theft that we overlook how odd it is for bandits to plan assiduously to educate their young. I do not wish to diminish those differences that had disturbed the prosecutor and the majority he represents. My point is that the band could be cast as exceptional only by stressing such differences and suppressing substantial similarities. This reveals how part of that majority's self-image was constructed out of a blend of

\footnotetext{
${ }^{8}$ Ibid., 190. Johns Hopkins University Press, 1991), xiv.

${ }^{10}$ Cobb, Reactions to the French Revolution, 192.

${ }^{11}$ Ibid., 190.
}

9 This mode of inference is noted in Edward Muir, 'Introduction: Observing Trifles,' in Microhistory and the Lost Peoples of Europe, ed. Edward Muir and Guido Ruggiero (Baltimore: 
similarities and differences. I think of it as a new kind of macro claim; it is not a claim about the prosecutor's intention or the image's function. Its significance depends on whether that construction can be used to clarify other macro phenomena.

What about interactions? From these, we can deduce a range of macro claims about society's situation. Some confirm old hypotheses, while others raise new ones. For instance, the band's interactions with outsiders indicate an 'elaborate chain of complicity' in its community. ${ }^{12}$ It used many middlemen. Innkeepers and local tenants provided information about wealthy victims. Seamstresses, clothes' salesmen, cattle-merchants, horse-dealers, counterfeiters, jewelers, and locksmiths disposed of stolen goods. ${ }^{13}$ The bandits 'returned, again and again, to the same inns ... to change, to eat and drink and play cards, while awaiting the arrival of customers to whom they could sell the clothes and stuff they had stolen-when they did not sell them, quite openly at the counter, to the landlord. $^{14}$

Their insouciance hints at how easily crime nested, in 'full sight,' within a rural community in revolutionary France. The community was attuned to this criminality-terrorized into silence, but sometimes filled with sympathy and admiration. ${ }^{15}$ Lest this diagnosis seem fanciful, Cobb reminds us that the band enjoyed at least ten years of virtual impunity, despite their crude and loud operations. 'The amazing thing is that they lasted as long as they did. ${ }^{16}$ Beyond the band and its immediate accomplices, there was probably 'a far wider circle at least of toleration or even semi-complicity, which the police could not breach. ${ }^{17}$

\footnotetext{
12 Ibid., 189.

${ }^{13}$ Ibid., 191.

${ }^{14}$ Ibid., 206.

${ }^{15}$ Ibid., 189.

${ }^{16}$ Ibid., 207.

${ }^{17}$ Ibid., 186.
} 
Outside reactions to the band can also be instructive. The pursuit of these bandits became 'une affaire d'État' for the Directory. ${ }^{18}$ After 150 suspects were rounded up in 1798, the investigating director feared that the band's allies would attack the prison. The Minister of War had to dispatch a garrison during the trial to prevent a break-out. ${ }^{19}$ Were these only personal worries? There is evidence that they express a wider climate of fear. Although the bandits committed crimes in several jurisdictions, the Minister of Justice and local officials were keen that they be tried together, in order to impress local opinion and 'exploit to the full such a signal victory for public order. ${ }^{20}$ From these reactions, we can infer a more general vulnerability in the police and judicial authorities of this period.

Do such data about fears and reactions belong at the macro level? We may be tempted to dismiss them as merely psychological, as though they were somehow less real or reliable than data about crime figures, police numbers, and judicial structures. Two reminders may help here. Institutional strength is a partly psychological attribute, so fears can be legitimate data for assessing it. ${ }^{21}$ Psychological data can also be constrained or corrected. We may discover, for instance, that the authorities' fears were limited to the countryside, not widespread in all of France. Or we may find a more plausible interpretation of their seemingly fearful behavior.

\subsection{Spurious Identifications}

Let me address two risks in these micro-to-macro inferences. The first risk: What if the identification of a marginal group is spurious? Suppose that the authorities

\footnotetext{
${ }^{18}$ Ibid., 182n.

${ }^{19}$ Ibid., 208.

${ }^{20}$ Ibid., 209.

${ }^{21}$ Cobb makes a similar point about the role of psychology in macro questions about subsistence. See Gwynne Lewis, 'Review: The People's Armies of the French Revolution,' The Historical Journal 32 (1989), 464; and Jones, 'Olwen Hufton's 'Poor',' 185.
} 
had been mistaken about the band's composition and behavior. Indeed, as Cobb notes, it is possible that they deliberately inflated the affair by 'creating a sort of amalgame' of 118 suspects and 'alleged activities. ${ }^{22}$ Unfortunately, historians have no easy way to verify both. They rely on police and judicial records for almost all data on the band.

This need not matter. We are partly interested in how the majority identifies the band because its terms of identification help us to deduce the majority's selfimage. What matters here are the kinds of behavior that the majority regarded as abnormal. We do not need to know exactly how many were in the band or how abnormally it behaved. We can use the official amalgam like a historiographical scaffold, eventually to be dismantled. But this will not work for all our micro-to-macro inferences. Take, for instance, the new macro claim about how the majority's self-image was constructed. To derive a useful version of this claim, it may be necessary to discover the majority's actual similarities with the band, which were obscured by the focus on their alleged differences. If so, we must identify the band's actual composition and behavior. Moreover, it may be useful to compare these with the majority's allegations. If they diverge substantially, we can infer that the majority had a poor grasp of reality and that its self-image was partly built on fantasy.

How then can a historian minimize the risk of spurious identification? Cobb relies, implicitly, on a norm of coherence: The macro-level identification of a marginal group is strengthened if we find a surprising micro-level coherence in its behavior. This coherence comes from making sense of behavior that looks, at first sight, to be inconsistent, unintelligent, or unintelligible. Here are three examples. First, to an outsider, the band's spurts of violence did not appear 'consistent or calculated. ${ }^{23}$ Sometimes they killed entire households; other times they spared families or individuals. They seemed to rape and murder at whim,

\footnotetext{
${ }^{22}$ Cobb, Reactions to the French Revolution, Appendix C; $181 \mathrm{n}$ and $186 \mathrm{n}$.

${ }^{23}$ Ibid., 198.
} 
rather than following any policy. There was no 'social protest' since the poor were just as likely to be targeted as the rich. ${ }^{24}$ But this apparent arbitrariness made sense within the band, creating a 'loose kind of hierarchy' among members based on their cruelty and physical prowess. ${ }^{25}$ Arbitrariness in unleashing violence was cultivated as a virile sign of cruelty. Second, the band's actions often seemed unintelligent. After an operation, they would show up at the inn, 'in their new clothes, spending freely and boasting in their cups. ${ }^{26}$ Their last leader, le Rouge d'Auneau, when captured, was happy to boast about their operation's details. ${ }^{27}$ Although these flamboyant actions might look foolish to outsiders, they expressed the band's pride and humor in flouting authority. Third, younger members seemed inexplicably preoccupied by personal appearance. ${ }^{28}$ The men took care to dress well, sometimes at high risk; the women were rewarded with fine clothing. Silver shoe buckles were prized. They stole far more clothing than other valuables. This was partly because clothing was easier to dispose of quickly. But band members were also proving themselves within a 'recognized hierarchy in a society of their own making,' in which their appearance had an exaggerated significance. ${ }^{29}$

Drawing on these interpretations, Cobb argues that the band's behavior often had a 'concealed symbolism' that cannot be explained by need and other 'purely material terms. ${ }^{30}$ This micro-level behavior had a strong and separate coherence. It reinforces our identification of the band as a marginal group, bearing 'its own signs of recognition, its own language, and its own shared

\footnotetext{
${ }^{24}$ Ibid., 205.

${ }^{25}$ Ibid., 200.

${ }^{26}$ Ibid., 205.

${ }^{27}$ Ibid., 208.

${ }^{28}$ Ibid., 200.

${ }^{29}$ Ibid., 204.

${ }^{30}$ Ibid., 201.
} 
assumptions. ${ }^{31}$ Such differences show that French society was even less like this marginal group than it had asserted.

\subsection{Insignificant Interactions}

Any unexpected coherence we find in a marginal group's behavior reinforces its independence from the majority. Unfortunately, this tends to exacerbate the second risk in micro-to-macro inferences. What if the interactions between a marginal group and its society prove to be insignificant? At first sight, this seems to threaten Cobb's case study. He reminds us that the band was an anti-society that had repudiated the Revolution and its workings. To the band and other such marginal groups, the Revolution was 'a magnificent irrelevance. ${ }^{32}$ If the Revolution had been so irrelevant to them, how can studying the band tell us anything interesting about French society?

Cobb's ingenious move is to invest new macro-level meanings in this very irrelevance. It means, first of all, that there were limits to the revolutionary authority's power in France. ${ }^{33}$ Despite the Revolution's ambition to impose its vision on France, its agents could not control the band and similar groups living in the margins of society. Second, these limits left enough room for marginal groups to resist authority in surprisingly productive ways. The band was able to establish 'its own codes, its own hierarchy, its own language, its own sense of time, and its own calendar' - in effect, to create its 'own history,' which lasted longer than any revolutionary regime at the center. ${ }^{34} \mathrm{~A}$ norm of challenge is at work here: A micro-level relation is significant if it challenges what we find meaningful at the macro level. To highlight these new meanings, Cobb has to

\footnotetext{
${ }^{31}$ Ibid., 202.

$32 \mathrm{Ibid} ., 125$. He begins this theme on 13 and returns to it on 163 , in a section entitled 'The Irrelevance of the Revolution.' Chapter 4 explores the complicated and contradictory ways in which 'it was possible almost to live outside the Revolution' (130).

${ }^{33}$ Ibid., 126.

${ }^{34} \mathrm{Ibid} ., 125$ and 178.
} 
orient our perspective even at the macro level toward the possibilities in marginal lives. 'For the Revolution exists as much through their narrow, unremarkable lives, or in their violent bloody enterprises, as in the lives of the great. $^{35}$ This is an assumption that underlies his entire book; to me, it indicates how deeply, and oddly, a democratic concern has found its way into Cobb's historical perspective.

But how can historians ensure that the audience shares their perspective? One tempting strategy is to impose on that audience any new meanings that they have found at the macro level. They might add, reasonably, that the proof of their worth lies in the historical interpretations that they enable. I think Cobb chooses a subtler strategy. He is guided by a policy of restraint: 'It is not always possible, or even desirable from the point of view of historical method, to bring out the pointers and establish the relationship between public and private acts. $^{, 36}$ Instead he invites the audience into his perspective, always allowing that his invitation-together with its package of new inferences and meanings-can be declined. Here is a passage on the band that illustrates this open historiographical attitude:

There was a certain logic in the position of the members of the bande d'Orgères and of many other similar groups, in deciding to create their own history (and myth), in a narrative of violence, pillage, and murder. They at least were, for a time, masters both of the present and of the immediate future; and no one can lightly dismiss a narrative, however anarchical and violent that, thanks to their efforts, to the fears that they inspired, and to the wide extent of the complicity that they enjoyed, they succeeded in keeping going for nearly ten years. . . ${ }^{37}$

\footnotetext{
${ }^{35}$ Ibid., 131. He describes, on 14, his goal to put that Revolution 'in a more human perspective.'

${ }^{36}$ Ibid., 130. On 92, he praises a book that is 'good almost by accident, by default': 'The author does not always realise just what a gold mine he has dug out, he is unwilling to obtrude ... and perhaps we should be grateful to him for having been hesitant to bring out the pointers.'

${ }^{37}$ Ibid., 178.
} 
By speaking of a 'logic,' Cobb reminds us of the strong and separate coherence in the band's behavior. This coherence forms a 'narrative' with its own new meanings, which ought not to be 'lightly' dismissed. However, he does not deny that this narrative can be legitimately dismissed. The audience is left to assess, for itself, what the costs of such a dismissal might be and whether it is willing to bear them. This openness is a striking aspect of Cobb's historical method. I see it as a form of generosity. To his audience, he offers an invitation to explore some marginal lives and engage in the new meanings that he finds in them. To those marginal lives, he offers a chance, 'whenever possible,' for them 'to witness for themselves, in their own language. ${ }^{38}$

This attitude explains another unusual aspect of Cobb's method. He is frank about his prejudices and sentiments. Of those revolutionary elites whom he ignores: he must 'admit to an extreme repulsion for Robespierre' and 'confess to a certain inability to understand the motives of those who seek to exercise power' during a Revolution. ${ }^{39}$ On the other hand, he finds a strange reassurance in those marginal lives to whom he draws our attention. It is 'reassuring to think of a great Revolution as a magnificent irrelevance. ${ }^{40}$ To him, studying this irrelevance is

a reassuring, even a hope-giving exercise, if one can take one's eyes off so much random killing and forget the costs, in personal and family terms, of murder and maiming. For it illustrates the limitless capacity of the individual to live out of reach of terrible and dangerous events and to shut the door on the shouting, the screams, the roars, the howls, the ugly surge of collective commitment and of vengeful lust. . . ${ }^{41}$

\footnotetext{
${ }^{38}$ Ibid., 131.

${ }^{39}$ Ibid., 5-6. See also 12, where he mentions being 'afraid of him.'

40 Ibid., 125. Jones, 'Olwen Hufton's 'Poor',' 184, notes how often the term 'reassuring' recurs in Cobb's writings.

${ }^{41}$ Cobb, Reactions to the French Revolution, 126. Lyons, 'Cobb and the Historians,' 14, finds this sympathy to be 'very questionable in practical, let alone moral terms.' I do not disagree, but want to ask why Cobb deliberately exposes himself to this kind of criticism.
} 
Why does Cobb resort to this bluntly personal, even confessional, talk of repulsion and reassurance? He cannot be asking us to share his prejudices and sentiments. (If he did, why spell them out so obviously as prejudices and sentiments?) I think he means to provoke a change in his audience's perspective. Without this change, the new macro-level inferences and meanings he draws from the marginal lives will not take hold. But, following the norm of restraint, Cobb does not want to impose his perspective on us or assume that we already share it. Instead, by recording the prejudices and sentiments that partly paved his way into that perspective, he implicitly invites us to find our own ways into it. This autobiographical honesty, therefore, complements his historiographical restraint. Both norms ought to be tested further by others: Might they reduce the danger that microhistorians will replace the grand narrative they attack with another of their own making ${ }^{42}$

\section{Monsters}

I now turn to look at Cobb's use of monsters. How does the history of a monster's life give us a better understanding of its society? Take this example in his book: Nicolas Guénot, an 'unusual, even interesting, monster' from the provinces. ${ }^{43}$ Drawing on a biography by Claude Hohl, Cobb describes a desperate life that started in Voutenay. Before he was 17, Guénot worked as a flotteur, rolling logs in the rivers to Paris. This was a dangerous trade conducted in an 'exceptionally brutal' community, where rich timber merchants ruthlessly exploited everyone. ${ }^{44}$ Guénot made his way to Paris, where he survived as a police informer and underworld auxiliary. At 21, he enlisted in the Gardes Françaises, notorious as 'the most brutal, violent, and undisciplined regiment of

\footnotetext{
${ }^{42}$ Sigurður Gylfi Magnússon highlighted this danger during a conference at which this essay was presented.

${ }^{43}$ Cobb, Reactions to the French Revolution, 97. Throughout this section, I draw on the perceptive analysis in Lyons, 'Cobb and the Historians,' 11-12.

${ }^{44}$ Cobb, Reactions to the French Revolution, 81.
} 
the old army. ${ }^{45}$ He was court-martialed and imprisoned several times, then dishonorably discharged at 29. When the Revolution came, Guénot seized his chance and entered the police and prison services. At 39, he became a full-time agent of the Committee of General Security-a position that allowed him, at the height of the Terror, to denounce and arrest a group of timber merchants from his old village. After the Revolution, he was sent back to Voutenay. Hounded by both vengeful notables and envious villagers, he survived for more than a decade as a 'wild man of the woods.' 46

Guénot is, in two ways, an especially tough test for micro-to-macro inferences. First, he exhibited the extreme behavior of a monster. This behavior was often incomprehensible. To his biographer, Guénot seemed to be a 'semi-monster' addicted to cruelty, violence, and vengeance. ${ }^{47} \mathrm{He}$ was a terrorist who could be 'singularly merciless, harsh, vengeful, and unscrupulous in pursuit of his enemies. ${ }^{48}$ When he was forced into a 'Crusoe-like' isolation in the woods, Guénot turned inhuman to some degree, even forgetting 'how to form coherent sentences.' Later, 'half mad' and 'muttering curses and obscenities,' he sometimes addressed the birds and trees. ${ }^{49}$ Second, because of his longevity, Guénot was 'exceptional' even among the terrorists. ${ }^{50}$ His career is 'unrepresentative of most middle-ranking terrorists'; few survived the White Terror and even fewer lived long enough to see the two Restorations. ${ }^{51}$

If Guénot seems too unusual be an archetype, must he become merely an anecdote? Has Cobb told us a tale of someone who 'happened to be alive at the

\footnotetext{
45 Ibid., 79.

${ }^{46}$ Ibid., 90.

${ }^{47}$ Ibid., 93.

${ }^{48}$ Ibid., 91.

${ }^{49}$ Ibid., 90 and 89.

${ }^{50}$ Ibid., 77.

${ }^{51}$ Ibid., 86.
} 
time of the Revolution'? ${ }^{52}$ His micro-level tale would then offer us no macro-level insights. Cobb is alert to this danger. He warns against the 'profitable, but footling trap' of anecdotalism. ${ }^{53}$ He means for us to infer new macro claims from Guénot's life, for he even states a version of the microhistorian's manifesto: 'to make such personal case histories witness for a wider sector of opinion and for elements of society unrepresented in the present account. ${ }^{54}$

\subsection{Postulates and Projections}

How can a monster serve as witness for its society? Here is Cobb's proposal:

'Nicolas Guénot, in fact, offers an almost ideal case history of the emergence of a terrorist mentality and of the progressive commitment, in individual terms, to the politics of violence. ${ }^{, 55}$ This suggests two related aims. First, we can use the history of a monster's life to tell us what to postulate about the society's mentalities. Second, we can use it to show us how to project individual motivations to explain the monster's behavior. Let me say how both aims involve new macro claims. What is the key postulate in this case? Cobb speaks of the 'slow, subterranean, perhaps unsuspected emergence of a terrorist mentality' from the pre-revolutionary period onwards. ${ }^{56}$ Within this social mentality, violence is an immediate and instinctive way to react. This is an attitude, rather than 'any form of coherent or organized opinion, openly expressed.' And it need

\footnotetext{
52 I borrow this useful formulation from Lyons, 'Cobb and the Historians,' 12.

${ }^{53}$ Cobb, Reactions to the French Revolution, 129.

54 Ibid., 10. Sven-Erik Klinkmann has drawn my attention to others who interpret a culture through its monsters. They tend to focus on the ways by which a culture identifies and represents monsters; their modes of inference thus resemble those that I discussed above in relation to marginal groups. See, for instance, Monster Theory: Reading Culture, ed. Jeffrey Jerome Cohen (Minneapolis: University of Minnesota Press, 1996) and Jeffrey Jerome Cohen, Hybridity, Identity, and Monstrosity in Medieval Britain: On Difficult Middles (London: Palgrave Macmillan, 2006). Cobb, as I interpret him, tries a different tack. He focuses on the monster's mentality, not its marginality.

${ }^{55}$ Cobb, Reactions to the French Revolution, 77.

${ }^{56}$ Ibid., 65.
} 
not be "particularly conscious. ${ }^{, 57}$ But it is not restricted to an individual: Guénot was 'almost pathologically violent; but so were his fellow-villagers.' Their collective attunement to violence was rooted in 'a life of hardship, deprivation, and brutality' during the decade before the Revolution. ${ }^{58}$ For Cobb, this macrolevel postulate adds to the 'neglected, but so important, history of mentalities. ${ }^{59}$

Once we have postulated this social mentality in the background, we can plausibly project individual motivations to explain Guénot's extreme behavior. His early start in a violent climate makes his later addiction to violent behavior more comprehensible. Given that social mentality, Guénot's pathologically violent streak can be interpreted as the product of at least three factors: 'rage and frustration at an unjust order of things,' 'temperament,' and 'long periods of heavy drinking in braggart military company. ${ }^{60}$ We can begin to make sense of his 'progressive commitment' to terrorist tactics-the 'ease and naturalness' with which he transformed from an exploited worker in violent company to a violent semi-criminal in the underworld, and then to a violent terrorist during the Revolution. The Revolution provided a unique chance for him to 'put his private violence to public use. ${ }^{61}$ During the Terror, he was motivated by a desire for power and vengeance against his former oppressors, as well as by crude political convictions. 'He enjoyed the Terror ... . was in it for what he could get out of it, and had the further satisfaction no doubt of feeling that the enemies of the Republic were also his own. ${ }^{62}$ His was a mix of recognizably human motivations.

\footnotetext{
57 Ibid., 175. See also 116: 'It would certainly be unwise . . . to make too much of conscious decision, deliberate ambition, clearly felt ideological conviction, or mere desire for power, as the only sources of revolutionary commitment.'

58 Ibid., 76.

59 Ibid., 91. This may be a deliberate echo of the mentalités discussed by Annales historians. On the troubled relation between Cobb and these historians, see Lyons, 'Cobb and the Historians,' 18-19; Lewis, 'Richard Cobb, 1917-1996,' 246; and Jones, 'Olwen Hufton's 'Poor',' 187-188. See also n. 90 below.

${ }^{60}$ Cobb, Reactions to the French Revolution, 82.

61 Ibid., 90.

62 Ibid., 84.
} 
Even Guénot's final isolation in the woods was not the result of madness or 'misanthropy alone'; it was partly motivated by his reasonable fear of retribution. $^{63}$

Through these projections, we endow a monster with "human proportions. ${ }^{64}$ Individual motivations can be used to explain those aspects of its behavior that were once deemed inexplicable. So the monster was rather more like the rest of its society. This leads to a new macro claim about French society's intelligibility. Previously, Guénot's extreme behavior marked a limit to that intelligibility. He seemed to be a monstrous singularity. Now, as a result of Cobb's postulate of a terrorist mentality and projections of some individual motivations, the total intelligibility of French society during the Revolution increases.

Might this new intelligibility go too far in reducing a monster's complexity? Let me highlight three ways in which this history of a monster's life need not be reductive. First, projections are not limited to self-interested motivations. Cobb is at pains to remind us that Guénot's 'baser instincts' were mingled with courage and 'some rudimentary convictions, even if they were derived largely from hatred and from the desire for vengeance. ${ }^{65}$ Second, postulates about social mentalities do not entail the assumption that individual lives are determined by social structures. Such postulates can be used, instead, as tools to recover the terrorist's individualism. ${ }^{66}$ For Cobb, it is the interplay between society's terrorist mentality and Guénot's individual motivations that makes sense of his life. He does not interpret Guénot and other terrorists as 'pawns in some vast enterprise of social structure mechanics. ${ }^{67}$ He portrays them as individuals 'caught up in'-and sometimes 'attempting to escape'-environment

\footnotetext{
${ }^{63}$ Ibid., 88.

${ }^{64}$ Ibid., 9.

${ }^{65}$ Ibid., 91 and 90.

${ }^{66} \mathrm{Ibid} ., 117$. On 10, he defends his book as a 'study of individualism.'

${ }^{67}$ Ibid., 131.
} 
and collective commitment. ${ }^{68}$ Guénot might be the 'product of a society, of a place, and of a trade,' but he did not end up like most flotteurs in Voutenay. ${ }^{69} \mathrm{He}$ had at least the 'independence' and 'perhaps the good sense' to leave for and linger in Paris. ${ }^{70}$ Third, different sets of projections and postulates may make equally good sense of Guénot. It is possible that someone else, who does not share Cobb's prejudices or social position, may offer us a different macro-level postulate to interpret Guénot's experience. ${ }^{71}$ If so, we shall have to choose the more plausible postulate or combine both postulates into a more complex portrayal of Guénot's society.

\subsection{Idle Postulates}

The first risk in micro-to-macro inferences based on a monster's life: What if the postulate of a social mentality is idle ${ }^{72}$ Suppose that a historian tries to account for Guénot's terrorist-like behavior by postulating a terrorist mentality in his society. Without elaboration, this postulate explains nothing about Guénot's behavior or French society. At most, it re-describes that behavior in convoluted terms, as expressive of a so-called terrorist mentality. It can be too easy to multiply macro-level mentalities in this empty fashion for all micro-level behaviors that we find incomprehensible. Everything, and thus nothing, will be explained. This risk stands out whenever Cobb gestures vaguely at the reach of the terrorist mentality: 'up and down the country, there must have been tens of

68. Ibid., 124.

69. Ibid., 94.

70. Ibid., 78.

71. I thank Jacques Revel for urging me to consider this important possibility. As I understand him, Professor Revel recommends that we clarify-and disaggregate if necessary-the social levels to which any macro claim refers.

72. I am alluding to Wittgenstein's images of an 'idling engine' and a wheel that 'can be turned though nothing else moves with it' so that it is 'not part of the mechanism'; see Ludwig Wittgenstein, Philosophical Investigations, transl. G. E. M. Anscombe, 3rd ed. (London: Blackwell Publishing, 1953). 
thousands of men like him, of whom we know little or nothing. ${ }^{, 73}$ He does not doubt that there were 'many more terrorists like him, though less discoverable. ${ }^{74}$ So what is the basis of his confidence?

As I read him, Cobb deploys a norm of connection here: A macro-level postulate is strengthened if it draws surprising connections between micro-level phenomena previously seen as distinct. The terrorist mentality, which Cobb postulates, not only accounts for Guénot's violent behavior during the Terror. It also connects that behavior with two other sets of micro-level phenomena. First, there is what happened to Guénot when he was sent back to Voutenay after the Revolution. His repeated and violent persecution by the community illustrates the 'everlasting memories of rural vengeance' and the 'administrative terror that was the common lot' in rural France under the Imperial regime. ${ }^{75}$ These later events fit the social mentality postulated by Cobb, in which violence is immediate and instinctive. Second, there is the 'bad, brutal school' that brought up the community. ${ }^{76}$ Everyone was accustomed, before the Revolution, to a nobility that inflicted violence, with impunity and insolence, on the lower orders and womenfolk. Even the government was savage; Cobb describes how it did not hesitate to 'employ terror' against rural law-breakers. Thus his postulate also receives some confirmation from concrete details about 'the reality of life . . . in ancien régime France.' 77

He also relies, implicitly, on a norm of provocation. A macro-level postulate is useful if it provokes productive questions about other micro-level phenomena. ${ }^{78}$

\footnotetext{
${ }^{73}$ Cobb, Reactions to the French Revolution, 82.

${ }^{74}$ Ibid., 90.

${ }^{75}$ Ibid., 91 and 87.

${ }^{76}$ Ibid., 93. He adds here that, to understand Guénot, we need to 'sufficiently relate the violence of the man to that of his background.'

77 Ibid., 94.

78 In his introduction, on 14, Cobb says that his book is 'designed as much to put forward deductions that may be proved wrong . . . or to suggest further lines of approach.' On the
} 
Cobb uses the postulate of a terrorist mentality to raise a new question: Did this social mentality influence the behavior of terrorists from 'a very different social origin'? For these terrorists, 'the distance between private life and public terrorism' seemed greater. ${ }^{79}$ To explore this question, Cobb considers the revolutionary career of Cochon de Lapperant, a provincial lawyer who rose to be second Minister of Police during the Revolution and sent many to their deaths. He explores various 'parallels' and 'contrasts' with Guénot and concludes that 'Cochon too was a terrorist, but, unlike Guénot, one by calculation, rather than by temperament or pre-disposition. ${ }^{80}$ Unfortunately, Cobb also finds Cochon to be a 'boring, very ordinary administrator' whose mentality it would be 'impossible to reconstruct. ${ }^{81}$ How far Cochon's calculations were influenced by the terrorist mentality and what his motivations were for terrorizing others: these remain, for us, open questions.

\subsection{Indulgent Projections}

The second risk: What if the projections of individual motivations to explain a monster's behavior turn indulgent? Cobb seeks to give 'human proportions' to the monster, but this may encourage a form of wishful thinking when we are dealing with the unknown motivations of obscure characters. If historians permit themselves to project motivations at the micro level in an unconstrained fashion, then the improved intelligibility of French society at the macro level will be illusory. Cobb does not ignore this risk. He notes that, in exploring the margins and monsters of revolutionary France, 'we are indeed groping in a zone d'ombre, into which we may at best have allowed to penetrate very occasional shafts of light-seldom the light of evidence or of concrete fact-more often that of

\footnotetext{
intellectual value of provocation: I have profited from discussions with Katherine J. Morris and Steve Woolgar.

${ }^{79}$ Cobb, Reactions to the French Revolution, 94.

${ }^{80}$ Ibid., 95.

${ }^{81}$ Ibid., 97.
} 
tentative, inventive perception, or, to put it more baldly, historical guessing. ${ }^{82}$ He even admits that he finds incomprehensible the motivations of those terrorists who bore or frighten him. This suggests that historians' interests and sympathies can influence their attempt to make sense of a monster's life. If so, the risk of indulgent projections is heightened.

This risk can be defused. One of my purposes in this essay has been to show that, beneath his 'historical guessing' and 'groping,' Cobb has built a subtle inferential structure. ${ }^{83}$ He often cannot verify the individual motivations of monsters directly by 'evidence' or 'concrete fact.' But this does not lead him to project those motivations in a fit of fantasy. Instead, his micro-level projections and macro-level postulates are mutually supportive inferences. The latter are also held in place by the useful connections and provocations that they make about other micro-level phenomena. Moreover, Cobb's postulates and projections are constrained by the micro- and macro-level discoveries of other 'more well-tried approaches. ${ }^{84}$ His case studies are meant to 'supplement,' not substitute for, those approaches.

A strategy of micro-level contextualization also offers some help. The projection of individual motivations is strengthened if we can embed them within their micro-level context. This strategy is easily misunderstood. ${ }^{85}$ When historians speak of 'contextualizing' a micro-level phenomenon, they usually place that phenomenon within its more macro-level settings. Their aim is to clarify the wider significance of the phenomenon by relating it to those settings. They are,

\footnotetext{
82 Ibid., 179. On 128, he admits: 'In this frontier zone of history, much will remain unstated, a great deal has to be guessed at, often on very thin evidence, something may even have to be invented.'

${ }^{83}$ See Lyons, 'Cobb and the Historians,' 11: 'Cobb's anti-method may claim to be impressionistic, but paradoxically it is based on exhaustive research.' He sees, in Cobb, 'an approach to historical investigation which almost amounts to a method.'

${ }^{84}$ Cobb, Reactions to the French Revolution, 126.

${ }^{85}$ I have learned from Levi, 'On Microhistory,' 111 and Revel, 'Microanalysis and the Construction of the Social,' 502, who distinguish two ways for historians to deploy context.
} 
as it were, working outwards. Cobb faces a different problem here. He must work inwards. He has already postulated the macro-level mentalities that may be the settings for a monster's behavior. Now he needs to figure out if some individual motivations, combined with those social mentalities, can be used to explain the monster's behavior. Contextualization, in this case, spells out the micro-level details of the monster's behavior and environment so that any new projections of motivations can gain traction.

I suggest that this is partly why Cobb lavishes such detail in his histories of Guénot and other monsters. He need not be indulging in 'the love of detail for its own sake,' refusing to place material in 'a general historical context' or reducing history to 'a string of anecdotes. ${ }^{86}$ Instead, I interpret him to be fulfilling a specific historiographical task: showing his audience the intricate context of micro-level details that justify his projections of individual motivations. Such projections then earn their keep, at the macro level, by increasing the intelligibility of French society. Here Cobb's literary skills in finding and presenting narrative detail have a historiographical role. They support his use of micro-level contextualization.

\section{Conclusion}

The challenge: How do micro cases in history lead us to surprising macro claims? In this essay, I focused on marginal groups and monsters. My main historiographical findings are summarized in the table below. First, I distinguished four kinds of micro-to-macro inferences. By looking at how a society identifies a marginal group and interacts with it, we can draw macro-level inferences about that society's self-image and situation. By making sense of a monster's life, we can draw macro-level inferences about its society's mentality and intelligibility. Then I identified four risks in these inferences. These are the risks of spurious identifications, insignificant interactions, idle postulates, and

\footnotetext{
${ }^{86}$ These are cited as three dangers in Lyons, 'Cobb and the Historians,' 12.
} 
indulgent projections. Finally, I showed how the norms of coherence, challenge, restraint, connection, provocation, and contextualization can be used to manage those risks.

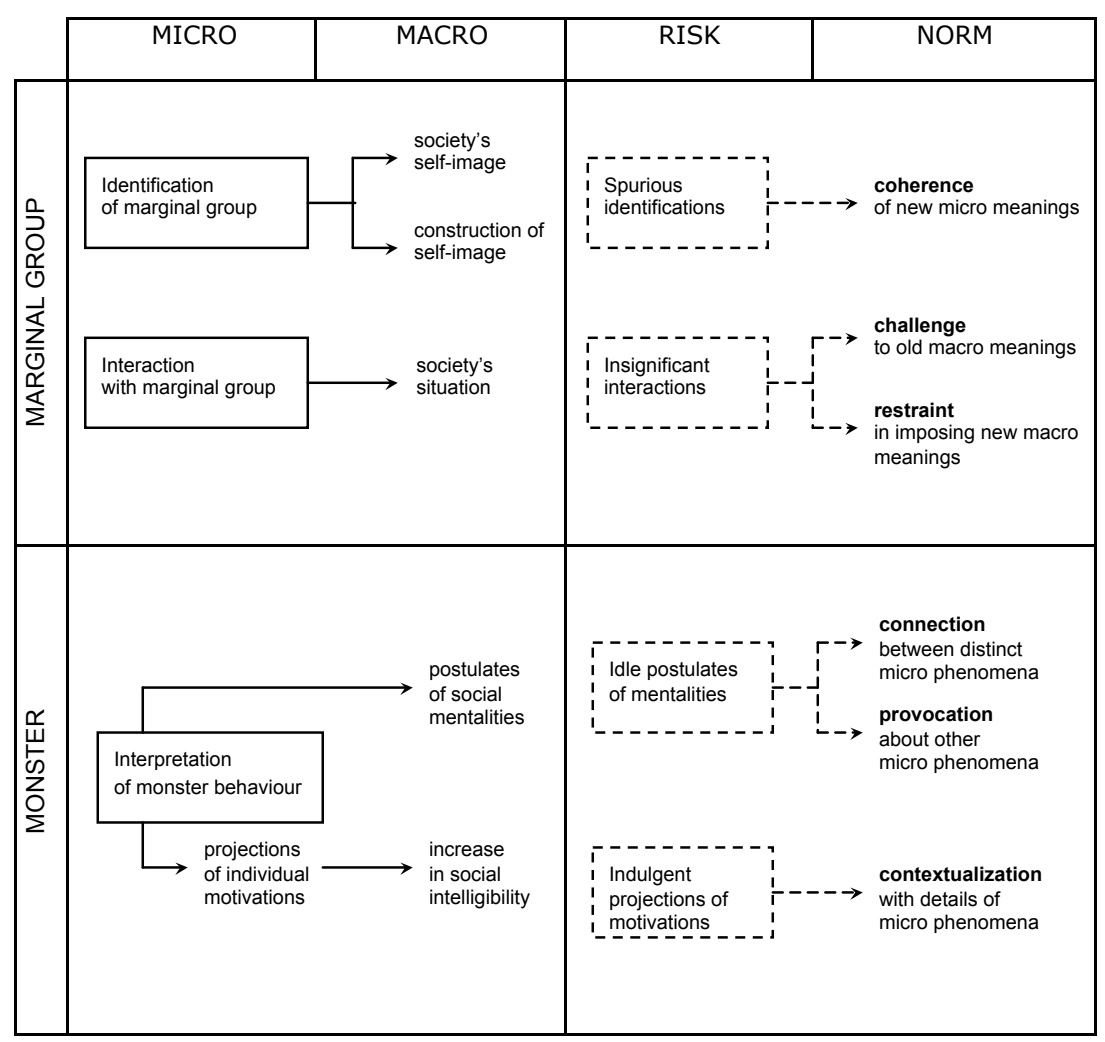

These four kinds of inferences suggest a joint criterion for assessing the macro significance of a micro case: How far does it improve our understanding of a society's self-image, situation, mentality, and intelligibility? The six norms of interpretation can then be translated into the following sub-criteria.

1. Does the case study find a surprising coherence in behavior at the micro level?

2. Does the case study confirm or challenge what we already accept as meaningful at the macro level?

3. Does the case study impose on the audience new meanings at the macro level, or does it invite the audience to engage with them?

4. Does the case study draw surprising connections between distinct phenomena at the micro level? 
5. Does the case study provoke productive questions about other phenomena at the micro level?

6. Does the case study contain sufficient details at the micro level to contextualize motivations, and at the macro level to contextualize mentalities?

I hope that spelling out these sub-criteria so bluntly will be useful. It is a first step to investigating how they ought to be applied and assessed together. What should historians do if these criteria come into conflict? I do not have a ready answer. However, these criteria already give us a better grasp of the multi-level context within which historians and others can appeal to 'coherence' as a theoretical ideal.

My historiographical findings are drawn from a close reading of Cobb's case studies about revolutionary France. The reading does not explore any connection between these case studies and his other writings or his debates with other historians about the French Revolution. It is, for better or worse, a micro study of a micro study. This leads to a reflexive worry: Do I face the same risks that I have found in Cobb ${ }^{87}$ Insofar as I base my macro claims about historiography on this micro study of Cobb's method, I have tried to manage the risks in his manner. First, I highlighted a neglected connection between Cobb's interest in micro-tomacro inferences and other historians' interest in them. Second, I identified a surprising coherence in the historiographical, autobiographical, and literary values of Cobb's case studies. These are tied to the implicit norms that govern his inferences. Third, I used Cobb's inferences to challenge what we count as macro claims. Then I used his norms to provoke new possibilities in how we conceive of margins and monsters, and in how we combine history with autobiography. Finally, I invite others to adapt these inferences and norms for their own use. They are not meant to be rigid rules imposed on anyone.

\footnotetext{
${ }^{87}$ I thank Brian Fay and an anonymous reader for pressing me to address this explicitly.
} 
This reading of Cobb is, primarily, a philosophical response. It comes from an abstract angle. But I claim no special authority for philosophers to interpret historians. I envisage a dialogue between them. For philosophers, the historiographical norms that manage micro and macro levels may transform some debates, in the philosophy of science and philosophy of mind, about reductionism between levels of theory or reality. ${ }^{88}$ After reading Cobb, I find it difficult to accept, at face value, philosophical claims about coherence or simplicity that focus on any one level. Might this focus unduly obscure the meanings at another level? My sub-criteria offer a way to check. For historians, especially those tempted into historiographical reflection, the philosophical tools that increase abstraction may clarify those norms underlying their practices.

Such a dialogue has its own risks. Even Cobb has warned against too much abstraction, though he was criticizing other historians, not philosophers. ${ }^{89}$ When I first offered my reading to others, a bemused French historian noted this oddity: Can one really find a methodology in Cobb? He is, after all, a 'confirmed empiricist.' The microhistorian Carlo Ginzburg also finds Cobb to be unsympathetic-an 'empiricist who claims to be superior to theoretical questions' and a 'confirmed cultivator of his own eccentricity. ${ }^{90}$ But I have shown that Cobb's avowed 'historical impressionism' is guided by an inventive

\footnotetext{
${ }^{88}$ A case study that uses this approach is in my 'Models as Interpreters (with a Case Study from Pain Science),' Studies in History and Philosophy of Science 42 (2011), 303-312. I show how the discovery of new micro-level phenomena (in neuroscience and physiology) led to a controversy about their macro-level meanings (in medicine and psychology). See also the suggestive last line in Giuseppina D'Oro, 'Historiographic Understanding,' in A Companion to the Philosophy of History and Historiography, ed. Aviezer Tucker (Oxford: Wiley-Blackwell, 2009): 'Conversely, the relevance of the philosophy of historiography to discussions in the philosophy of mind is yet to be recognized.'

${ }^{89}$ For a taste of his polemic, see Richard Cobb, 'Historians in White Coats,' Times Literary Supplement (December 3, 1971), 1527-1528. Two earlier reviews are unsigned, in accordance with the newspaper's practice then: 'À Bas La Révolution!,' Times Literary Supplement (January 7, 1965), 8 and 'Annalists' Revolution,' Times Literary Supplement (September 8, 1966), 819-820. I note that his animus is usually directed at the 'crude,' 'rigid,' 'schematic,' or 'mechanistic' use of abstract theories and structures. He praises two older colleagues, Georges Lefebvre and Albert Soboul, when they use these cautiously and flexibly to frame their more intricate analyses.

${ }^{90}$ Ginzburg, 'Microhistory: Two or Three Things That I Know about It,' 16-17. But see n. 48 on 23, where he acknowledges an instance of Cobb's methodological awareness.
} 
historiographical sensibility. His is a risky style of history that gropes after its own rigors. He writes a history of margins and monsters in order to unwrite the received histories of the non-marginal and non-monstrous. He studies obscure individuals in order to find 'lost attitudes, pre-suppositions, assumptions, and submerged mentalities. ${ }^{91}$ He postulates social mentalities in order to make room for individual motivations. He flaunts his prejudices in a display of restraint. He uses autobiographical means for historiographical ends. Each apparent eccentricity is turned into a productive possibility. Almost every one of them offends a neat dichotomy that the philosopher in me craves; and yet Cobb strikes me as a deeply philosophical writer, constantly questioning the method and authority by which he writes history. He worries openly about his use of 'personal case histories,' hoping that he has 'not attempted to read in them too much or to push them too far. ${ }^{92}$ 'Better' history is, for him, not always history that is more certain and 'less tentative. ${ }^{93}$ What he wants are new angles of vision and a language that can include 'a multitude of suggestions, while leaving all channels conveniently open. ${ }^{94}$ If this be empiricism, it is one always attuned to experiment.

\footnotetext{
${ }^{91}$ Cobb, Reactions to the French Revolution, 179.

92 Ibid., 10. I do not fully understand how Cobb distinguishes 'too much' from 'too far.' Perhaps these critical terms are related, respectively, to what I call indulgent projections and idle postulates.

${ }^{93}$ Ibid., 17 and 128.

94 Ibid., 179.
} 